\title{
Exploring e-learning among nurse educators in undergraduate nursing
}

\author{
Melba Sheila D'Souza ${ }^{1}$, Subrahmanya Nairy Karkada ${ }^{2}$, Ramir Castro ${ }^{3}$ \\ 1. Department of Adult Health and Critical Care, Sultan Qaboos University, Muscat, Sultanate of Oman. 2. Department of \\ Business Studies, Higher College of Technology, Al Khuwair, Muscat, Oman. 3. Department of Fundamentals and \\ Administration, Sultan Qaboos University, Muscat, Sultanate of Oman.
}

Correspondence: Melba Sheila D'Souza. Address: Department of Adult Health and Critical Care, Sultan Qaboos University, Muscat, Sultanate of Oman. Email: melba123@rediffmail.com

Received: January 10, 2014

Accepted: March 19, 2014

DOI : $10.5430 /$ jnep.v4n7p73

URL: http://dx.doi.org/10.5430/jnep.v4n7p73

Online Published: April 28, 2014

\section{Abstract}

Background: Nurse educators' use blended learning pedagogy to support student centered learning in undergraduate curriculum. E-learning technology has been used to engage students in conceptual and experiential opportunities in higher education.

Objective: The objective of the study was to explore the perceptions of use and satisfaction of e-learning (Moodle) among nurse educators in an undergraduate nursing curriculum.

Methods: A cross-sectional research design was used among 50 nurse educators in undergraduate nursing in February 2010. Ethical approval was sought from the College ethics committee. A validated and reliable self-administered Faculty Satisfaction Survey was used to collect data. Inferential statistics was used to analyze the data.

Results: Nurse educator's perceptions were divergent, acknowledging the benefits of moodle, while some of them expressed concerns regarding over-time, limited resources, increased workload, and poor technical support. Some of the nurse educators exhibited positive attitudes towards the pedagogical value of moodle in engaging students, while some lacked the confidence to embark on developing courses using moodle.

Conclusion: The study showed a rising awareness of the use of e-learning among nurse educators and moderate satisfaction as a blending learning approach.

Implication: Nurse educators may need to incorporate moodle in the teaching-learning at a self-directed pace, using flexibility and convenience for higher learning approaches.

\section{Key words}

E-learning, Online learning, Blended learning, Information technology, Moodle, Mobile learning, Satisfaction, Nurse educators, Undergraduate curriculum

\section{I ntroduction}

There is a rapid growth in information communication technology with an increased focus on innovative educational delivery methods. As the use of e-technology becomes more popular, its consequences on learning outcomes in nursing 
should be considered. Nurse educators have recognized the need to integrate e-learning technology into nursing education ${ }^{[1]}$. E-learning is endorsed as a tool for developing the $21^{\text {st }}$ century skills among nurses required to function effectively in the knowledge economy ${ }^{[2,3]}$. Nurse educators are increasingly using computer-assisted learning to enhance educational delivery ${ }^{[4,5]}$ and integrate blended learning into teaching-learning processes ${ }^{[6]}$. This provides consistency of educational delivery ${ }^{[7]}$, reduces instruction time ${ }^{[8]}$, enhances effectiveness and mastery of learning, improves retention ${ }^{[9]}$ and increases student motivation ${ }^{[10]}$, satisfaction ${ }^{[11]}$ and enjoyment in learning ${ }^{[12]}$.

E-learning is an innovative approach for delivering well-designed, learner-centered, interactive, and facilitated learning environment ${ }^{[13]}$. Incorporation of critical thinking and communication strategies in e-learning positively impacts on student satisfaction in a web-based course ${ }^{[14]}$. A continual interaction using e-learning between undergraduate nursing students and nurse educators enhances student satisfaction and enriches their learning. Web-based learning among graduate students' reported significantly higher stimulation in learning than the conventional lecture group ${ }^{[15]}$. Students' gained significant satisfaction with the multimedia delivery of courses ${ }^{[16]}$. E-learning strategies enable students to be independent, have a self-directed learning and self-discipline ${ }^{[17]}$. Hence expertise of nurse educators in use of e-learning is significant for student satisfaction and depth of learning ${ }^{[18]}$.

\subsection{Background}

There is an increasing rate of web and online usage within all sectors, especially younger Arab students and nurse educators ${ }^{[19]}$.The implementation of WebCT at an Omani public university found that 3000 student users revealed that they favored the use of moodle in learning and faculty insisted on increased time in developing these courses ${ }^{[20]}$. Web-assisted instruction was found to be more effective than face-to-face instruction in terms of student achievement and positive attitudes ${ }^{[21]}$. Web-enhancement in nursing creates flexibility and enhances critical thinking through learning experiences and reflective activity ${ }^{[22]}$. There is a dearth of studies regarding nurse educator's perspectives related to use of e-learning in the nursing curriculum.

The BSN nursing education is the first in the Sultanate of Oman with multi-cultural faculty. Within this BSN curriculum, the use of 'e-learning' as a blended learning strategy is a new concept among nurse educators in the Middle East. There is a paradigm shift from teaching to learning in this school of nursing. Exploring the factors that positively shape e-learning will assist nurse educators to increasingly use e-learning technology. Hence, this study explores the use and satisfaction of e-learning among nurse educators in the undergraduate nursing curriculum. The findings have relevance to nurse educators as lifelong learning and are essential to maintain knowledge, practice and professional competency in Oman.

\subsection{Conceptual framework}

The Instructivist learning teacher-centered model (Moule et al.) was adopted for the study ${ }^{[23]}$. This e-learning model describes technology-enhanced learning that spans instructivist to constructivist approaches (see Figure 1). In our study instructivist learning theory (teacher centered) model of learning suggests knowledge exists independently of leaner. The constructivist theory (student focused) describes the student who constructs new knowledge through analysis of information and reference to experience and understanding. The e-learning ladder base identifies applications that give access to instructional material. The ladder presents a range of technologies that exist with the potential to enhance learning and a number of factors that impact on their adoption and use. The effective use of e-learning depends on the levels of computer literacy, academic background, nursing culture and social networks to adopt e-learning among nurse educators.

\subsection{Study aim}

The aim of the study was to explore the use of e-learning and satisfaction using moodle (e-learning) for teaching-learning among nurse educators in undergraduate curriculum in the Middle east. 


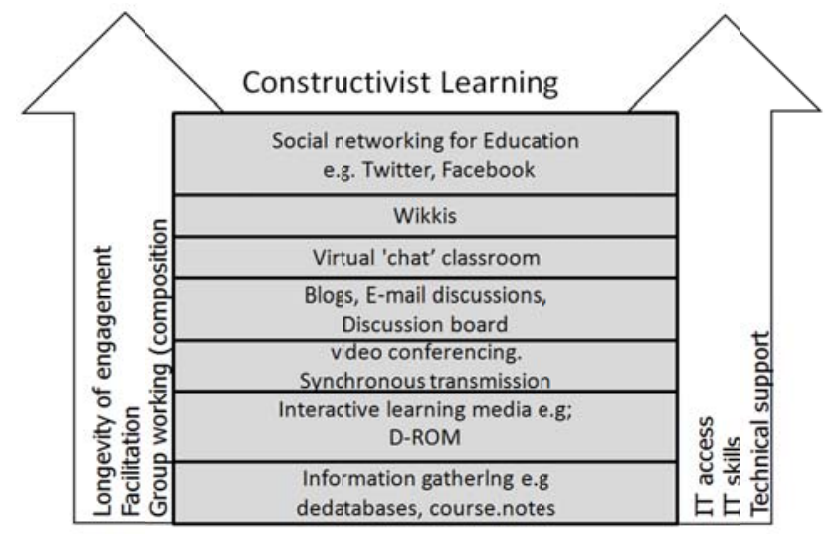

Instructivist

Figure 1. Instructivist learning- teacher centered model among nurse educators

\section{Methods}

\subsection{Study design}

The study used a cross-sectional research design to explore the perceptions regarding use and satisfaction of e-learning among nurse educators in the undergraduate nursing curriculum.

\subsection{Sample size, setting and participants}

Sample size was determined using $\mathrm{G}^{*}$ Power software using chi-square for goodness of fit test, and contingency table ${ }^{\text {[24] }}$. The sample size was calculated at a power of $95 \%$ using $5 \%$ level of significance with a medium effect size of 0.3 with alpha $5 \%$. Hence the sample size required was 50 nurse educators. The total number of nurse educators available in the school of nursing in a public university was 50. All these nurse educators were included in the study in January 2010.

\subsection{Human ethics}

Ethical approval was obtained from the College Research Committee, Sultan Qaboos University in January 2010. After obtaining ethical permission, 50 nurse educators were recruited, informed and provided written information regarding the study. It outlined that participation was entirely voluntary, that they could withdraw at any time. Extreme care was taken to adhere to human and ethical principles.

\subsection{Data collection}

The nurse educators were provided a covering letter to describe the purpose, instructions, informed consent and data collection instruments. Written and verbal consent was obtained among those who volunteered to participate in the study. It was emphasized that the aim of the study was purely to elicit perceptions of nurse educators. Confidentiality and anonymity would be maintained. The participants who voluntarily participated in the study completed the questionnaires, placed it in a sealed envelope and returned them to the investigators. All the data were locked and treated confidentially. The data was double checked, entered and coded in the SPSS 20 version.

\subsection{Development of study instruments}

An extensive literature was conducted regarding use and satisfaction of web and e-learning among nurse educators to develop the data collection instruments ${ }^{[25,26]}$. The data collection instruments were:

- $\quad$ Teaching-learning with technology tool (TLT) was used to assess teaching activities or communication used in the moodle course (12 items), priorities and importance of moodle ( 8 items). It had a combined 3-point rating 
scale from always, frequently and never and a checklist with very important and not important. E.g. sound clips in class room, websites as extra resources, quizzes online, discussion forums, enhancing class room teaching, teacher-student communication, practice learning, assessment.

- Teaching-learning readiness tool (TLR) assessed the factors related to nurse educator's (14 items) and student's readiness ( 6 items) in using moodle. E.g. support and guidance, time, training, development.

- $\quad$ Faculty satisfaction survey (FSS) developed by Bolliger and Wasilik ${ }^{[26]}$ was used to assess satisfaction at the level of student, faculty and institution using a 4-point Likert scale ranging from strongly disagrees to strongly agree. It had 28 items with three subdomains related to student (15 items), faculty (9 items) and institution (4 items).E.g. level of interactions with students in moodle course, actively involved in learning, few resources when teaching, access course anytime at convenience.

- Demographic tool had 8 items consisting of age, gender, experience, qualification, number of students, number of courses, and satisfaction.

\subsection{Validity and reliability}

The data collection instruments were validated by an educational designer, informatics specialist and a nurse educator. These tools were found to be valid. Internal consistency reliability was assessed with Cronbach's alpha coefficient. The internal reliability for the TLT, TLR and FSS instruments was $0.71,0.73$ and 0.86 respectively.

\section{Results}

\subsection{Demographic characteristics ( see Table 1)}

Half percentage of the nurse educators were above 40 years (54\%) and had more than 15 year experience (44\%). Majority of them were female (88\%) and had postgraduate education (82\%). Some of the nurse educators have used moodle in less than $5(82 \%)$. Some of them reported satisfaction using moodle as blended learning approach (88\%).

Table 1. Demographic characteristics among nurse educators $(\mathrm{N}=50)$

\begin{tabular}{|c|c|c|c|c|}
\hline & Demographic characteristics & Category & $\boldsymbol{F}$ & $\mathbf{P}(\%)$ \\
\hline \multirow{2}{*}{1} & \multirow{2}{*}{ Age (years) } & $<40$ & 23.00 & 46.00 \\
\hline & & $>40$ & 27.00 & 54.00 \\
\hline \multirow{2}{*}{2} & \multirow{2}{*}{ Gender } & Female & 44.00 & 88.00 \\
\hline & & Male & 6.00 & 12.00 \\
\hline \multirow{3}{*}{3} & \multirow{3}{*}{ Total experience (years) } & $<10$ & 14.00 & 28.00 \\
\hline & & $10-15$ & 14.00 & 28.00 \\
\hline & & $>15$ & 22.00 & 44.00 \\
\hline \multirow{2}{*}{4} & \multirow{2}{*}{ Qualification (Nursing) } & Baccalaureate/Masters & 41.00 & 82.00 \\
\hline & & Doctorate & 9.00 & 18.00 \\
\hline \multirow{3}{*}{5} & \multirow{3}{*}{ Number of students in a course } & $<25$ & 19.00 & 38.00 \\
\hline & & $25-50$ & 14.00 & 28.00 \\
\hline & & $>50$ & 17.00 & 34.00 \\
\hline \multirow{2}{*}{6} & \multirow{2}{*}{ Number of courses using moodle } & $<5$ & 41.00 & 82.00 \\
\hline & & $5-15$ & 9.00 & 18.00 \\
\hline \multirow{3}{*}{7} & \multirow{3}{*}{ Satisfaction using moodle } & Outstanding & 3.00 & 6.00 \\
\hline & & Good & 44.00 & 88.00 \\
\hline & & Average & 3.00 & 6.00 \\
\hline
\end{tabular}




\subsection{Teaching-learning with technology among nurse educators (see Table 2)}

Nurse educators commonly reported use of the moodle in teaching and communicating activities. They 'always' reported using quiz and tests (80\%), virtual world sites (90\%) and chats/forums/blogs $(86 \%)$. They also expressed use of moodle for assessment (78\%), records online (72\%) and social networking site (72\%) while teaching.

\subsection{Priorities in moodle among nurse educators (see Table 2)}

Nurse educators prioritized various areas for developing, implementing and delivery of moodle. Some of them reported diversity and accessibility in learning (62\%), online assessment (46\%) and technical knowledge and support (40\%) as quiet important.

Table 2. Teaching-learning with technology and Priorities among nurse educators $(\mathrm{N}=50)$

\begin{tabular}{|c|c|c|c|c|c|c|c|}
\hline & Teaching-learning with technology & Always & $\%$ & Frequently & & Never & $\%$ \\
\hline 1 & Communicate & 17.00 & 34.00 & 13.00 & 26.00 & 20.00 & 40.00 \\
\hline 2 & Powerpoint, film, sound clips, lectures & 20.00 & 40.00 & 15.00 & 30.00 & 3.00 & 6.00 \\
\hline 3 & Suggest websites & 5.00 & 10.00 & 17.00 & 34.00 & 20.00 & 40.00 \\
\hline 4 & Quizzes and tests online & 40.00 & 80.00 & 8.00 & 16.00 & 2.00 & 4.00 \\
\hline 5 & Assessments online & 39.00 & 78.00 & 10.00 & 20.00 & 1.00 & 2.00 \\
\hline 6 & Records online & 36.00 & 72.00 & 14.00 & 28.00 & 50.00 & 0.00 \\
\hline 7 & Online simulations & 26.00 & 52.00 & 16.00 & 32.00 & 8.00 & 16.00 \\
\hline 8 & Mobile phones, ipad, ipod, smart TV & 8.00 & 16.00 & 21.00 & 42.00 & 4.00 & 8.00 \\
\hline 9 & Social networking sites & 36.00 & 72.00 & 4.00 & 8.00 & 4.00 & 8.00 \\
\hline 10 & Virtual world site & 45.00 & 90.00 & 3.00 & 6.00 & 2.00 & 4.00 \\
\hline 11 & Discussion forums & 19.00 & 38.00 & 6.00 & 12.00 & 13.00 & 26.00 \\
\hline \multirow[t]{2}{*}{12} & Chats/ forums, blogs & 43.00 & 86.00 & 6.00 & 12.00 & 1.00 & 2.00 \\
\hline & Priorities in moodle & $\begin{array}{l}\text { Quite } \\
\text { important }\end{array}$ & $\%$ & $\begin{array}{l}\text { Not } \\
\text { important }\end{array}$ & $\%$ & & \\
\hline 1 & Classroom teaching & 10.00 & 20.00 & 40.00 & 80.00 & & \\
\hline 2 & Teacher-student, peer communication & 14.00 & 28.00 & 36.00 & 72.00 & & \\
\hline 3 & Practice skills learning & 11.00 & 22.00 & 15.00 & 30.00 & & \\
\hline 4 & Online assessments, exercises & 23.00 & 46.00 & 20.00 & 40.00 & & \\
\hline 5 & Technical support & 20.00 & 40.00 & 12.00 & 24.00 & & \\
\hline 6 & Independent, interprofessional learning & 10.00 & 20.00 & 15.00 & 30.00 & & \\
\hline 7 & Diversity and accessibility & 31.00 & 62.00 & 19.00 & 38.00 & & \\
\hline 8 & Family-friendly modules, improve retention & 5.00 & 10.00 & 19.00 & 38.00 & & \\
\hline
\end{tabular}

\subsection{Teaching-learning readiness among nurse educators ( see Table 3)}

Some nurse educators reported administrative decision-making (48\%) and self-perceived negativism (62\%) related to readiness to use of moodle. They also reported use of electronic course content (34\%), quality of teaching (22\%), staff development (32\%), workload (36\%) and new teaching challenges $(30 \%)$ as related factors.

\subsection{Faculty satisfaction among nurse educators (see Table 4)}

Less than half of the nurse educators strongly agreed with the access to moodle courses at any time (48\%) and lacked face-to-face contact with students $(36 \%)$. While some of the nurse educators agreed with the active involvement in learning (30\%), students access moodle at any place (22\%), opportunity to reach students $(22 \%)$ and level of teacher-student interaction (20\%). Few nurse educators strongly agreed that few resources $(16 \%)$, frustration with technicality (18\%) and wider range of resources (18\%). Some faculty agreed that they were satisfied with teaching $(54 \%)$ and use of moodle regardless of technical concerns (22\%). $30 \%$ of the nurse educators strongly agreed that they were satisfied with workload, preparation and course evaluations. 
Table 3. Teaching-learning readiness among nurse educators $(\mathrm{N}=50)$

\begin{tabular}{|c|c|c|c|c|c|}
\hline & Faculty related readiness & All the times & $\%$ & Sometimes & $\%$ \\
\hline 1 & Reliable network, equipment, office rooms & 7.00 & 14.00 & 43.00 & 86.00 \\
\hline 2 & Electronic course content & 17.00 & 34.00 & 33.00 & 66.00 \\
\hline 3 & Support and guidance, need to change & 3.00 & 6.00 & 8.00 & 16.00 \\
\hline 4 & Time to prepare, confidence, motivation, background in computers & 4.00 & 8.00 & 9.00 & 18.00 \\
\hline 5 & Student IT skills & 5.00 & 10.00 & 14.00 & 28.00 \\
\hline 6 & Physical health, enthusiasm, positive perception & 8.00 & 16.00 & 42.00 & 84.00 \\
\hline 7 & E-learning available, Course management, evaluation & 7.00 & 14.00 & 9.00 & 18.00 \\
\hline 8 & Quality of teaching at university & 11.00 & 22.00 & 39.00 & 78.00 \\
\hline 9 & Staff development, tech, IT training, & 16.00 & 32.00 & 33.00 & 66.00 \\
\hline 10 & Workload & 18.00 & 36.00 & 32.00 & 64.00 \\
\hline 11 & University/ College decision-making & 24.00 & 48.00 & 26.00 & 52.00 \\
\hline 12 & Basic, more advanced features, funds & 2.00 & 4.00 & 27.00 & 54.00 \\
\hline 13 & Negative perceptions & 31.00 & 62.00 & 19.00 & 38.00 \\
\hline \multirow[t]{2}{*}{14} & Particular students or courses, new teaching challenge & 15.00 & 30.00 & 35.00 & 70.00 \\
\hline & Students related readiness & All the times & $\%$ & Sometimes & $\%$ \\
\hline 1 & Age, gender & 44.00 & 88.00 & 6.00 & 12.00 \\
\hline 2 & Physical ability & 36.00 & 72.00 & 14.00 & 28.00 \\
\hline 3 & Previous level of attainment, learning experience & 17.00 & 34.00 & 33.00 & 66.00 \\
\hline 4 & Positive or negative attitude towards the technology & 9.00 & 18.00 & 41.00 & 82.00 \\
\hline 5 & Expectations, commitment and application & 6.00 & 12.00 & 44.00 & 88.00 \\
\hline 6 & $\begin{array}{l}\text { Response to and experience of previous/ recent learning, perceptions, } \\
\text { Existing competence/familiarity in the use of technology }\end{array}$ & 5.00 & 10.00 & 22.50 & 45.00 \\
\hline
\end{tabular}

Table 4. Faculty satisfaction using Moodle among nurse educators $(\mathrm{N}=50)$

\begin{tabular}{|c|c|c|c|c|c|c|c|c|c|}
\hline No & Satisfaction with moodle & $\begin{array}{l}\text { Strongly } \\
\text { agree } \mathrm{F}\end{array}$ & $\begin{array}{l}\mathbf{P} \\
(\%)\end{array}$ & $\begin{array}{l}\text { Agree } \\
\text { F }\end{array}$ & $\begin{array}{l}\mathbf{P} \\
(\%)\end{array}$ & $\begin{array}{l}\text { Disagree } \\
\text { F }\end{array}$ & $\begin{array}{l}\mathbf{P} \\
(\%)\end{array}$ & $\begin{array}{l}\text { Strongly } \\
\text { disagree } \\
\text { F }\end{array}$ & $\begin{array}{l}\mathbf{P} \\
(\%)\end{array}$ \\
\hline S1 & Level of teacher-student interactions & & 0.00 & 10.00 & 20.00 & 24.00 & 48.00 & 16.00 & 32.00 \\
\hline S2 & Flexibility & & 0.00 & 4.00 & 8.00 & 19.00 & 38.00 & 27.00 & 54.00 \\
\hline S3 & Actively involved in their learning. & & 0.00 & 15.00 & 30.00 & 23.00 & 46.00 & 12.00 & 24.00 \\
\hline S7 & Miss face-to-face contact with students & 18.00 & 36.00 & 1.00 & 2.00 & 10.00 & 20.00 & 21.00 & 42.00 \\
\hline $\mathrm{S} 10$ & $\begin{array}{l}\text { Students are very active in } \\
\text { communicating }\end{array}$ & & 0.00 & 8.00 & 16.00 & 29.00 & 58.00 & 13.00 & 26.00 \\
\hline S11 & $\begin{array}{l}\text { Access my e-learning course any time } \\
\text { at my convenience. }\end{array}$ & 24.00 & 48.00 & 1.00 & 2.00 & 7.00 & 14.00 & 18.00 & 36.00 \\
\hline $\mathrm{S} 12$ & $\begin{array}{l}\text { Students are more enthusiastic about } \\
\text { their learning than their traditional } \\
\text { counterparts. }\end{array}$ & & 0.00 & 5.00 & 10.00 & 28.00 & 56.00 & 17.00 & 34.00 \\
\hline S16 & $\begin{array}{l}\text { Satisfied with the use of } \\
\text { communication tools }\end{array}$ & & 0.00 & 5.00 & 10.00 & 17.00 & 34.00 & 28.00 & 56.00 \\
\hline S17 & $\begin{array}{l}\text { Better feedback to my e-learning } \\
\text { students on their performance in the } \\
\text { course. }\end{array}$ & & 0.00 & 4.00 & 8.00 & 16.00 & 32.00 & 30.00 & 60.00 \\
\hline S19 & $\begin{array}{l}\text { Students are somewhat passive to } \\
\text { contacting the instructor }\end{array}$ & 3.00 & 6.00 & 1.00 & 2.00 & 17.00 & 34.00 & 29.00 & 58.00 \\
\hline $\mathrm{S} 20$ & $\begin{array}{l}\text { Students can access my e-learning } \\
\text { course from any place in the world. }\end{array}$ & & 0.00 & 11.00 & 22.00 & 19.00 & 38.00 & 20.00 & 40.00 \\
\hline S21 & $\begin{array}{l}\text { Participation level of my students in } \\
\text { the class discussions is lower }\end{array}$ & & 0.00 & 2.00 & 4.00 & 38.00 & 76.00 & 10.00 & 20.00 \\
\hline
\end{tabular}


Table 4. (Continued.)

\begin{tabular}{|c|c|c|c|c|c|c|c|c|c|}
\hline No & Satisfaction with moodle & $\begin{array}{l}\text { Strongly } \\
\text { agree F }\end{array}$ & $\begin{array}{l}P \\
(\%)\end{array}$ & $\begin{array}{l}\text { Agree } \\
\text { F }\end{array}$ & $\begin{array}{l}\mathbf{P} \\
(\%)\end{array}$ & $\begin{array}{l}\text { Disagree } \\
\text { F }\end{array}$ & $\begin{array}{l}P \\
(\%)\end{array}$ & $\begin{array}{l}\text { Strongly } \\
\text { disagree } \mathbf{F}\end{array}$ & $\begin{array}{l}\mathbf{P} \\
(\%)\end{array}$ \\
\hline $\mathrm{S} 25$ & $\begin{array}{l}\text { Not meeting my e-learning students } \\
\text { face-to-face }\end{array}$ & 4.00 & 8.00 & 3.00 & 6.00 & 14.00 & 28.00 & 29.00 & 58.00 \\
\hline $\mathrm{S} 27$ & $\begin{array}{l}\text { Gratifying because it provides me } \\
\text { with an opportunity to reach } \\
\text { students }\end{array}$ & & 0.00 & 11.00 & 22.00 & 17.00 & 34.00 & 22.00 & 44.00 \\
\hline \multirow[t]{3}{*}{$\mathrm{S} 28$} & $\begin{array}{l}\text { More difficult for me to motivate my } \\
\text { students }\end{array}$ & 9.00 & 18.00 & 1.00 & 2.00 & 3.00 & 6.00 & 37.00 & 74.00 \\
\hline & Mean & 3.90 & 7.80 & 5.47 & 10.93 & 18.73 & 37.47 & 21.93 & 43.87 \\
\hline & Standard deviation & 9.13 & 14.94 & 4.49 & 8.97 & 8.90 & 17.80 & 7.81 & 15.63 \\
\hline F4 & Fewer resources & 8.00 & 16.00 & 6.00 & 12.00 & 20.00 & 40.00 & 16.00 & 32.00 \\
\hline F5 & Technology is reliable. & & 0.00 & 6.00 & 12.00 & 29.00 & 58.00 & 15.00 & 30.00 \\
\hline F8 & $\begin{array}{l}\text { Not problems controlling my } \\
\text { students }\end{array}$ & & 0.00 & 6.00 & 10.20 & 36.00 & 73.47 & 8.00 & 16.33 \\
\hline F9 & $\begin{array}{l}\text { Look forward to teaching my next } \\
\text { e-learning course. }\end{array}$ & & 0.00 & 6.00 & 12.00 & 28.00 & 56.00 & 16.00 & 32.00 \\
\hline F13 & $\begin{array}{l}\text { More creative resources used for the } \\
\text { e-learning course. }\end{array}$ & & 0.00 & 7.00 & 14.00 & 20.00 & 40.00 & 23.00 & 46.00 \\
\hline F14 & $\begin{array}{l}\text { Frustrating because of technical } \\
\text { problems. }\end{array}$ & 9.00 & 18.00 & 7.00 & 14.00 & 15.00 & 30.00 & 19.00 & 38.00 \\
\hline F18 & More satisfied with teaching & & 0.00 & 27.00 & 54.00 & 18.00 & 36.00 & 5.00 & 10.00 \\
\hline $\mathrm{F} 22$ & $\begin{array}{l}\text { Students use a wider range of } \\
\text { resources in the e-learning }\end{array}$ & 9.00 & 18.00 & 10.00 & 20.00 & 1.00 & 2.00 & 30.00 & 60.00 \\
\hline \multirow[t]{3}{*}{$\mathrm{F} 23$} & $\begin{array}{l}\text { Technical problems do not } \\
\text { discourage me. }\end{array}$ & & 0.00 & 11.00 & 22.00 & 34.00 & 68.00 & 5.00 & 10.00 \\
\hline & Mean & 2.89 & 5.78 & 9.56 & 19.11 & 22.33 & 44.67 & 15.22 & 30.44 \\
\hline & Standard deviation & 0.58 & 8.69 & 6.80 & 13.74 & 10.83 & 21.89 & 8.33 & 16.63 \\
\hline I6 & Higher workload & 15.00 & 30.00 & 1.00 & 2.00 & 13.00 & 26.00 & 21.00 & 42.00 \\
\hline I15 & $\begin{array}{l}\text { Takes me longer to prepare for an } \\
\text { e-learning course on a weekly basis }\end{array}$ & 15.00 & 30.00 & 1.00 & 2.00 & 16.00 & 32.00 & 18.00 & 36.00 \\
\hline $\mathrm{I} 24$ & $\begin{array}{l}\text { Fair compensation for e-learning } \\
\text { teaching. }\end{array}$ & 2.00 & 4.08 & 20.00 & 38.78 & 17.00 & 34.69 & 11.00 & 22.45 \\
\hline \multirow[t]{3}{*}{ I26 } & Receiving lower course evaluations & 15.00 & 30.00 & 11.00 & 22.00 & 5.00 & 10.00 & 19.00 & 38.00 \\
\hline & Mean & 11.75 & 23.50 & 8.25 & 16.50 & 12.75 & 25.50 & 17.25 & 34.50 \\
\hline & Standard deviation & 6.50 & 14.45 & 9.14 & 17.76 & 5.44 & 11.06 & 4.35 & 8.48 \\
\hline
\end{tabular}

Note. Subscales: Student - S, Faculty - F and Institute - I, F-Frequency, Percentage- \%

\subsection{Faculty satisfaction and demographic characteristics (see Table 5)}

Age, qualification, number of students, number of courses using moodle and satisfaction using moodle was found to be significant with faculty satisfaction at $5 \%$ level of significance.

Table 5. Association between faculty satisfaction and demographic characteristics using Pearson Chi square $(\lambda)$

\begin{tabular}{lll}
\hline Demographic characteristics & $\boldsymbol{\lambda}$ value & $\boldsymbol{p}$ \\
\hline Age & 11.868 & $0.04^{*}$ \\
Gender & 15.589 & 0.75 \\
Experience & 22.764 & 0.62 \\
Qualification & 15.290 & $0.05^{*}$ \\
Number of students in a course & 9.791 & $0.02^{*}$ \\
Number of courses using Moodle & 7.217 & $0.09^{* *}$ \\
Satisfaction using moodle & 11.086 & $0.01^{*}$ \\
\hline
\end{tabular}

$* p<.05$ level of significance, $* * p<.10$ level of significance

Published by Sciedu Press 


\section{Discussion}

In our study nurse educators reported use of e-learning (moodle) in courses using quiz, notes/powerpoints, videos, networking, and chats/forums/blogs. This enhances communication in teaching, exchange of information with students, and accessibility to moodle facilitates learning. The students had an opportunity to interact with teachers and peers and perceived connection in the learning process ${ }^{[27,28]}$. Powerpoints for tutorials, communicating with students via email, suggesting websites as extra resources, online simulation exercises, posting lecture notes on course websites, using film clips or sound clips were considered useful for teaching ${ }^{[25,29]}$. Qualified nurses engaged in post-registration courses have shown improved clinical practice as a result of e-learning and improved clinical decision-making using e-learning/moodle. Online student records and assessment, videoconferencing and social networking sites were reported by fewer staff was 'advanced' computer users ${ }^{[25]}$.

Nurse educators in our study used moodle for active learning, participation and communication with students. They reported enhanced classroom teaching and teacher-student relationship and student-student communicationmore important than assessment and e-learning ${ }^{[25]}$. The importance of developing 'learning centered' courses as opposed to 'content-centered courses' ${ }^{[30]}$ ensures that students are engaged and learning rather than just focusing on presentation of material. If good pedagogic practice is incorporated into e-learning materials, then higher-order learning may take place ${ }^{[23,31]}$. Students engage in an interactive communication with teacher and peer which encourages intellectual challenge and interest ${ }^{[32,33]}$. Hence use of moodle increases teacher-student contact time and improves the quality of the learning experience by addressing diverse student needs.

Nurse educators in our study reported developing moodel course content, guidance, networking and information technology skills that influenced their readiness and satisfaction using moodle. Lack of confidence, time and work load, technical support, hinders readiness to use e-learning. Student's previous experience, motivation and commitment to group learning experience in higher levels affect their readiness to use e-learning. Nurse educator expressed concerns about the development and delivery of good quality resources for e-learning as time intensive, need for expertise and increasing work-load ${ }^{[34,35]}$. Easy access to web-based learning courses by students was experienced by registered nurses'. Some nursing students were motivated to engage in self-directed and independent learning ${ }^{[36]}$. Nurse educators use case scenarios, flexibility and peer communication, support, knowledge validation in e-learning approaches ${ }^{[37]}$. Interactivity, practice exercises, repetition and feedback improved learning outcomes ${ }^{[38]}$.

In our study nurse educators were concerned with student's high expectations using moodle, need for higher range of e-learning resources, technical support, time management and course evaluations. They build competencies in use of moodle incorporating information technology in teaching and monitor patterns of students access to moodle and track records. They reported increased workload and preparation time and development using moodle. Instructors using e-learning invest more time than teaching face-to-face ${ }^{[39-41]}$ and need to maintain competencies ${ }^{[42]}$. Although they consider e-learning is an effective mode of delivery enhancing teaching-learning ${ }^{[43,44]}$. Age, qualification, number of students, number of courses using moodle and satisfaction using moodle was found to be significant with faculty satisfaction. They experienced a range of e-learning resources as an adjunct to didactic mode of delivery and learning experiences. Faculty, student and institution satisfaction are important as they influence motivation using e-technology in effective learning and sustainability ${ }^{[26]}$.

\section{Conclusion}

The findings of the study highlight the factors influencing e-learning as a blended learning approach to engage students in the learning process. These nurse educators reported flexibility, support and effective communication through stimulating, reflective, interactive and engaging learning strategies. E-learning environments with student engagement and improve learning experiences may be significant to learning outcomes ${ }^{[45]}$ and support face-to-face delivery ${ }^{[23]}$. This encourages 
student-teacher interaction for active learning, reciprocity and cooperation. Use of e-learning helps to develop higher analytical skills through review and discussion of case studies, evidence based practice, culture of safety and ongoing feedback. However, some proportion of nurse educators identified concerns related to over-time preparation in development and implementation, adequate resources in delivery and technical support as priority to develop courses incorporating moodle. Faculty satisfaction can affect motivation and commitment, as it is time consuming and demanding ${ }^{[46,47]}$ which is one of the five pillars of quality outcomes like student satisfaction, learning effectiveness, access and institutional cost-effectiveness ${ }^{[47]}$. E-learning will be integrated extensively within nursing curriculums with reconceptualization of the student learning process. It can be efficient and improve the quality of education in a cost effective way ${ }^{[48,49]}$. Expansion of e-learning to support constructivist approaches may help to respond to diversity in student learning needs. They need to be adaptable to preference style of learning and self-directed use of nurse educators to enhance integration of theory to practice. This creates transparency in the teaching-learning process and opportunities for student-teacher interaction and student engagement. Hence e-learning is integral for commitment to lifelong learning among nurse educators.

\section{I mplications for practice and education}

There is a need for open door policy for use of e-learning with restricted user name and password protection and security to access to review the learning management system. Clinical applications of continuing competencies and confidence in clinical practice and education will be increased with access and use of moodle via mobile learning like smart phones and ipads. Nurse educators can develop learning centered courses based on the e-learning model of higher learning resources and applications. Finks' theoretical principles of significant learning like knowledge, application, integration, human dimension, caring, learning how to learn can be used to develop higher thinking and clinical reasoning. Linking these elements creates a paradigm shift to constructivist learning. E-learning can be applied to clinical, laboratory and class room teaching through the use of computer and technology software in which students engage in virtual campus and simulated scenarios. Specific arrangements should be made for technical support personnel to assist nurse educators with hardware and software difficulties. Telephone and on-site consultation service might reduce anxiety and unexpected concerns. As e-learning is known as a 'revolution in education' ${ }^{[50]}$, stringent institutional policies and professional development opportunities ${ }^{[51,52]}$ will help to enhance e-learning applications in undergraduate nursing curriculum.

\section{Limitations}

This study refers to use of moodle (e-learning) in teaching, and cannot assume that the results apply equally to other e-learning environments. The sample size was small so the findings can be generalized to homogenous situations.

\section{Highlights}

1) Integration of e-learning in teaching-learning process creates flexibility and enhances learning experiences.

2) Increased need for time management, allocation of resources and technical support among nurse educators.

3) Moderate satisfaction of e-learning as a blended learning approach for student learning and expected achievement.

\section{Acknowledgements}

The authors gratefully acknowledge the content experts for valuable suggestions and Mr Reginald Roach, Senior Lecturer, Language Centre SQU for the meticulous editing of the manuscript. 


\section{References}

[1] Horiuchi, S., Yaju, Y., Koyo, M., Sakyo, Y., Nakayama, K. Evaluating of a web-based graduate continuing nursing education program in Japan: a randomized controlled trial. Nurse Education Today. 2009; 29: 140-149.

PMid:18829141http://dx.doi.org/10.1016/j.nedt.2008.08.009

[2] Gresty K., Skirton H. \&Evendon A. Addressing the issue of e-learning and online genetics for health professionals. Nursing and Health Sciences. 2007; 9: 14-22. PMid:17300540http://dx.doi.org/10.1111/j.1442-2018.2007.00296.x

[3] Bradwell P. The Edgeless University: Why Higher Education Must Embrace Technology. Demos, London; 2009.

[4] Paladino, Y., Peres, H. E-learning: a comparative study for knowl-edge apprehension among nurses. The Revista LatinoAmericana de Enfermagem. 2007; 15(3): 397-403. http://dx.doi.org/10.1590/S0104-11692007000300006

[5] Mcvey, G., Gusella, J., Tweed, S., Ferrari, M. A controlled evaluation of web-based training for teachers and public health practitioners on prevention of eating disorders. Eating Disorders. 2009; 17: 1-26. PMid:19105058 http://dx.doi.org/10.1080/10640260802570064

[6] Glen, S. E-learning in nursing education: Lessons learnt? Nurse Education Today. 2005; 25(6):415-417. PMid:16054949http://dx.doi.org/10.1016/j.nedt.2005.07.001

[7] Lancaster, T., Stead, L.Self-help interventions for smoking cessa-tion. Cochrane Database of Systematic Reviews. 2005; (3).

[8] Hsiao Sheen, S.-T., Chang, W.-Y., Chen, H.-L., Chao, H.-L., Tseng, C. E-learning education programme for registered nurses: the experience of a teaching medical center. Journal of Nursing Research. 2008; 16(3): 195-200. PMid:18792889 http://dx.doi.org/10.1097/01.JNR.0000387306.34741.70

[9] Jang, K., Hwang, S., Park, S., Kim, Y., \& Kim, M. Effects of a web-based teaching method on undergraduate nursing students' learning of electrocardiography. Journal of Nursing Education. 2005; 44(1): 35-39. PMid:15673173

[10] Tsai, S.-L., Tsai, W.-W., Chai, S.-K., Sung, W.-H., Doong, J.-L., Fung, C.-P. Evaluation of computer assisted multimedia instruction in intravenous injection. International Journal of Nursing Studies. 2004; 41: 191-198. http://dx.doi.org/10.1016/S0020-7489(03)00130-5

[11] Yu S. \& Yang K.-F. Attitudes toward web-based distance learning among public health nurses in Taiwan: A questionnaire survey. International Journal of Nursing Studies. 2006; 43: 767-774. PMid:16253261http://dx.doi.org/10.1016/j.ijnurstu.2005.09.005

[12] Lahti M, Hätönen H, Välimäki M. 2014. Impact of e-learning on nurses' and student nurses knowledge, skills, and satisfaction: a systematic review and meta-analysis. Int J Nurs Stud. 2014 Jan; 51(1): 136-49. PMid:23384695 http://dx.doi.org/10.1016/j.ijnurstu.2012.12.017

[13] Sit J.W.H., Chung J.W.Y., Chow M.C.M. \& Wong T.K.S. Experiences of online learning: students' perspective. Nurse Education. Today. 2005; 25: 140-147. PMid:15701540 http://dx.doi.org/10.1016/j.nedt.2004.11.004

[14] Cega, L., Norman, I., Marks, I. Computer-aided vs. tutorial-delivered teahing of exposure therapy for phobia/panic: randomized controlled trial with pre-registration nursing students. International Journal of Nursing Studies. 2007; 44: 397-405. PMid:16631177 http://dx.doi.org/10.1016/j.ijnurstu.2006.02.009

[15] Wilkinson A., While A.E. \& Roberts J. Measurement of information and communication technology experience and attitudes to e-learning of students in the healthcare professions: integrative review. Journal of Advanced Nursing. 2009; 65(4): 755-772. PMid:19228242 http://dx.doi.org/10.1111/j.1365-2648.2008.04924.x

[16] Beeckman, D., Scoonhoven, L., Boucque, H., Van Maele, G., Defloor, T. Pressure ulcers - e-learning to improve classification by nurses and nursing students. Journal of Clinical Nursing. 2008; 17: 1697-1707.PMid:18592624 http://dx.doi.org/10.1111/j.1365-2702.2007.02200.x

[17] Thiele, J. E. Learning patterns of online students. Journal of Nursing Education. 2003; 42: 364-366. PMid:12938899

[18] Bloomfield, J., Roberts, J., While, A. The effects of computer assisted learning versus conventional methods on the acquisition and reten-tion of handwashing theory and skills in pre-qualification nursing students: a randomized controlled trial. International Journal of Nursing Studies. 2010; 47:287-294. PMid:19762016 http://dx.doi.org/10.1016/j.ijnurstu.2009.08.003

[19] Khan, B.H.Managing E-Learning: Design, delivery, implementation and evaluation. Hershey, PA: Information Science Publishing, 2005. http://dx.doi.org/10.4018/978-1-59140-634-1

[20] Al Musawi, A.S. \&Abdelraheem, A.Y. E-Learning at Sultan Qaboos University: Status and future [Electronic Version]. British Journal of Educational Technology. 2004; 35(3): 363-367. http://dx.doi.org/10.1111/j.0007-1013.2004.00394.x

[21] Osman, M. \& Ahmed, H. Web-assisted instruction: Its potentials and impact on students' learning and attitudes. Paper presented at the Conference of the Center for Educational Technology (ETEX 2003), Sultan Qaboos University, Sultanate of Oman; 2003.

[22] Ali, N. S., Hodson-Carlton, K. \& Ryan, M. Students' perceptions of online learning: implications for teaching. Nurse Educator. 2004; 29: 111-115. PMid:15167578 http://dx.doi.org/10.1097/00006223-200405000-00009 
[23] Moule P., Ward R. \&Lockyer L. Nursing and healthcare students' experiences and use of e-learning in higher education. Journal of Advanced Nursing. 2010; 66(12): 2785-2795. PMid:20946565 http://dx.doi.org/10.1111/j.1365-2648.2010.05453.x

[24] Faul F., Erdfelder E., Lang A.-G. \& Buchner A. G*Power 3: a flexible statistical power analysis program for the social, behavioral, and biomedical sciences. Behaviour Research Methods. 2007; 39: 175-191. http://dx.doi.org/10.3758/BF03193146

[25] Blake, H. Staff perceptions of e-learning for teaching delivery in healthcare. Learning in Health and Social Care. 2009; 8(3): 223-234. http://dx.doi.org/10.1111/j.1473-6861.2009.00213.x

[26] Bolliger, D. U. and Wasilik, O. Factors influencing faculty satisfaction with online teaching and learning in higher education. Distance Education. 2009; 30(1):103-116. http://dx.doi.org/10.1080/01587910902845949

[27] Rovai, A.P., Ponton, M.K., \& Baker, J.D. Distance learning in higher education: programmatic approach to planning, design, instruction, evaluation, and accreditation. New York: Teacher's College Press, 2008.

[28] Thorpe, M., \& Godwin, S. Interaction and e-learning: The student experience. Studies in Continuing Education. 2006; 28(3): 203-221. http://dx.doi.org/10.1080/01580370600947330

[29] Schwier, R.A. Connections: Virtual learning communities. Saskatoon, SK: Copestone; 2011.

[30] Magnussen L. Applying the Principles of Significant Learning in the e-learning environment. Journal of Nursing Education. 2008; 47: 82-86. PMid:18320960 http://dx.doi.org/10.3928/01484834-20080201-03

[31] Kulier R., Hadley J.,Weinbrenner S. et al. Harmonising evidence-based medicine teaching: a study of the outcomes of e-learning in five European countries. BMC Medical Education. 2008; 8: 27. PMid:18442424 http://dx.doi.org/10.1186/1472-6920-8-27

[32] Moule P.E-learning for healthcare students: developing the communities of practice framework. Journal of Advanced Nursing. 2006; 53(3): 370-380. PMid:16629921 http://dx.doi.org/10.1111/j.1365-2648.2006.03813.x

[33] Moule P. Challenging the five-stage model for e-learning: a new approach. ALT-J. 2007; 15(1): 39-52.http://dx.doi.org/10.1080/09687760601129588

[34] Adams, A. \& Timmins, F. Students views of integrating web based learning technology into the nursing curriculum. Nurse Education in Practice. 2006; 6(1): 12-22. PMid:19040851http://dx.doi.org/10.1016/j.nepr.2005.05.005

[35] Moule, P., Albarran, J. W., Bessant, E., Brownfield, C., Pollock, J. A non-randomized comparison of e-learning and classroom delivery of basic life support with automated external defibrillator use: a pilot study. Int J Nurs Pract. 2008 Dec; 14(6): $427-34$. PMid:19126070 http://dx.doi.org/10.1111/j.1440-172X.2008.00716.x

[36] Creedy, D.K., Mitchell, M., Seaton-Sykes, P., Cooke, M., Patterson, E., Purcell, C., et al.Evaluating a web-enhanced bachelor of nursing curriculum: perspectives of third year students. Journal of Nursing Education. 2007; 46(10): 460-467. PMid:17955743

[37] Carroll, C.,Booth, A.,Papaioannou, D.,Sutton, A.,Wong, R. UKhealth-careprofessionals'experienceofon-linelearningtechniques: asystematicreviewofqualitativedata.J Contin Educ Health Prof. 2009; 29(4): 235-41. PMid:19998474http://dx.doi.org/10.1002/chp.20041

[38] Cook, D., Levinson, A., Garside, S. Instructional design variations in internet-based learning for health profession education: a systematic review and meta-analysis. Academic Medicine. 2010; 85(5): 909-922. PMid:20520049 http://dx.doi.org/10.1097/ACM.0b013e3181d6c319

[39] Cavanaugh, J. Teaching online - A time comparison. Online Journal of Distance Learning Administration. 2005; 8(1).

[40] Conceição, S.C.O. Faculty lived experiences in the online environment. Adult Education Quarterly. 2006; 57(1): 26-45. http://dx.doi.org/10.1177/1059601106292247

[41] Spector, J.M. Time demands in online instruction. Distance Education. 2005; 26(1): 5-27.http://dx.doi.org/10.1080/01587910500081251

[42] Jiang, W.W., Chen, W. \& Chen, Y.C. Important computer competencies for the nursing profession. Journal of Nursing Research. 2004; 12: 213-226. PMid:15362013 http://dx.doi.org/10.1097/01.JNR.0000387505.98877.6d

[43] Billings, D.M., Skiba, D.J. \& Connors, H.R. Best practices in web-based courses: Generational differences across undergraduate and graduate nursing students. Journal of Professional Nursing. 2005; 21(2): 126-133. PMid:15806511 http://dx.doi.org/10.1016/j.profnurs.2005.01.002

[44] Hegney, D., Eley, R., Buikstra, E., Fallon, T., Isoar,J. \& Gilmore, V. Australian nurses access and attitudes to information technology. Studies in health technology and informatics. 2006; 122: 688-692. PMid:17102351

[45] Reime M., Harris A., Aksnes J. \&Mikkelsen J. The most successful method in teaching nursing students infection controle-learning or lecture? Nurse Education Today. 2008; 28(7): 798-806. PMid:18442872 http://dx.doi.org/10.1016/j.nedt.2008.03.005

[46] Gallagher-Lepak, S., Reilly, J., and Killion, CM. Nursing student perceptions of community in online learning. Contemporary Nurse. 2009; 32(1-2): 133-146. PMid:19697984 http://dx.doi.org/10.5172/conu.32.1-2.133

[47] Sloan Consortium. Faculty satisfaction. Needham, MA: Sloan C Wiki. Retrieved August 28, 2008. Available from: http://www.sloan-c-wiki.org/wiki/index. 
[48] Lu, D. F., Lin, Z.C and Li, Y. J. Effects of a Web-Based Course on Nursing Skills and Knowledge Learning, Journal of Nursing Education. 2009February; 48(2). PMid:19260398 http://dx.doi.org/10.3928/01484834-20090201-10

[49] Rutowski, A.F. \&Spanjers, R.W.L. Optimising e-learning in healthcare for nurses.International Journal of Healthcare Technology and Management. 2007; 8: 354-369. http://dx.doi.org/10.1504/IJHTM.2007.013168

[50] Ruiz, J.G., Mintzer, M.J. \& Leipzig, R.M. The impact of e-learning in medical education. Academic Medicine. 2006 ; 81: $207-212$. PMid:16501260 http://dx.doi.org/10.1097/00001888-200603000-00002

[51] Harrington, S., Walker, B. Teaching ergonomics to Nursing facility managers using computer-based instruction. Journal for Nurses in Staff Development. 2006; 22(5): 260-268. PMid:17019283 http://dx.doi.org/10.1097/00124645-200609000-00010

[52] Moule, P., Ward, R. \&Lockyer, L. Issues with e-learning in nursing and health education in UK: are new technologies being embraced in the teaching and learning environments? Journal of Research in Nursing. 2010; 15(4): 1-14. 